\title{
Evaluation of Thoracic Complications After Urological Operations: A Single-center Experience
}

\author{
Ürolojik Operasyonlar Sonrası Ortaya Çıkan Torasik Komplikasyoların Değerlendirilmesi: \\ Tek-merkez Deneyimi
}

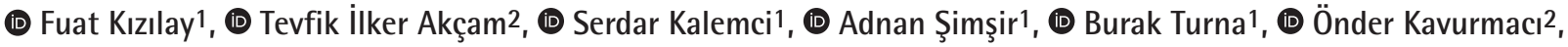 \\ (D) Ufuk Çağırıcı², (D) 0ktay Nazlı1, (D) Ceyhun Özyurt1, (D) Ibrahim Cüreklibatır ${ }^{1}$ \\ 1 Ege University Faculty of Medicine, Department of Urology, İmir, Turkiye \\ 2Ege University, Faculty of Medicine, Department of Thoracic Surgery, Izmir, Turkiye
}

\section{What's known on the subject? and What does the study add?}

Thoracic complications are a major complication of urological surgery. Complications are an inevitable part of urological surgery due to the increasing number of cases and complexity in recent years. There are some data on thoracic complications after urological laparoscopic surgery in the literature, while data on a thorough analysis of the thoracic complications of urological surgery is limited. In this study, we present the thoracic complications of the cases operated in our clinic and the treatment methods performed by the thoracic surgery clinic. We concluded that early diagnosis of thoracic complications and coordinated work with thoracic surgery are fundamental.

\section{Abstract}

Objective: To present cases of thoracic complications that developed after urologic interventions and were treated in collaboration with thoracic surgery.

Materials and Methods: Patients who were operated in the urology clinic at our hospital between January 2014 and December 2017 and required thoracic surgery consultation were retrospectively reviewed. Forty-two patients with pneumothorax, pleural effusion, hydropneumothorax and diaphragm injury were included in the study. Six patients, who had preoperative diaphragm invasion and underwent preoperative diaphragm incision, were excluded.

Results: Tube thoracostomy (T) was applied in only 5 patients who developed pneumothorax. Three patients with isolated pleural effusion were treated with $\Pi$ and 3 with thoracentesis. All patients who developed hydropneumothorax were found to have undergone nephrectomy (3 left, 1 right). All patients with iatrogenic diaphragmatic injury were diagnosed perioperatively and all of these patients were nephrectomized (5 right, 1 left). All the patients underwent primary diaphragm repair and 5 patients underwent $\Pi$. The mean duration of tube drainage was $5.5 \pm 2.1$ (2-13) days. The mean length of hospital stay in patients who underwent percutaneous nephrolithotomy, nephroureterectomy, nephrectomy and prostatectomy with thoracic complications was $4.12 \pm 1.08,8.26 \pm 2.87,4.04 \pm 1.23$ and $4.17 \pm 0.72$ days, respectively. There was no significant difference in mean duration of hospital stay between patients with and without thoracic complications ( $p=0.729$ ).

Conclusion: Thoracic complications may develop after urological interventions. In particular, evaluation of chest pain in patients with right-sided percutaneous nephrolithotomy and nephrectomy by chest X-ray is important for early diagnosis.

Keywords: Pneumothorax, Hydropneumothorax, Complication, Percutaneous Nephrolithotomy, Nephrectomy

$\ddot{0 z z}$

Amaç: Bu çalışmada ürolojik girişimler sonrası torasik komplikasyon gelişen ve göğüs cerrahisi-üroloji işbirliği ile tedavi edilen olgular sunuldu. Gereç ve Yöntem: Ocak 2014 - Aralık 2017 tarihleri arasında hastanemiz Üroloji Anabilim Dalı tarafından opere edilen ve göğüs cerrahisi konsültasyonu istenilen olgular retrospektif incelendi. Çalışmaya pnömotoraks, plevral effüzyon, hidropnömotoraks ve diyafragma yaralanması

Correspondence: Fuat Kızılay MD, Ege University Faculty of Medicine, Department of Urology, İzmir, Turkiye Phone: +90 2323902515 E-mail: fuatkizilay@gmail.com ORCID-ID: orcid.org/0000-0003-1856-0404 Received: 17.01.2019 Accepted: 31.01 .2019

Cite this article as: Kızılay F, Akçam Ti, Kalemci S, Şimşir A, Turna A, Kavurmacı Ö, Çağııııı U, Nazıı O, Özyurt C, Cüreklibatır İ. Evaluation of Thoracic Complications After Urological Operations: A Single-center Experience. J Urol Surg 2019;6(3):184-189.

๑Copyright 2019 by the Association of Urological Surgery / Journal of Urological Surgery published by Galenos Publishing House. 
saptanan 42 hasta dahil edildi. Operasyon öncesi diyafragma invazyonu saptanan ve peroperatif diyafragma insizyonu yapılan altı hasta çalışmadan çıkarıldı.

Bulgular: Pnömotoraks gelişen hastaların sadece 5'ine tüp torakostomi (T) uygulandı. İzole plevral effüzyon izlenen hastaların 3'ü $\Pi, 3$ 'ü ise torasentez ile tedavi edildi. Hidropnömotoraks gelişen hastaların tamamına nefrektomi (3 sol, 1 sağ) uygulandığı görüldü. İyatrojenik diyafragma yaralanması gelişen hastaların tamamına perioperatif dönemde tanı kondu ve hastaların tamamı nefrektomi (5 sağ, 1 sol) hastası idi. Hastaların tamamında diyafragmanın primer onarımı yapıldı, 5 hastaya $\Pi$ uygulandı. Hastaların ortalama dren kalış süresi 5,5 $\pm 2,1$ (2-13)/gündü. Toraks komplikasyonu gelişen hastalardan perkütan nefrolitotomi, nefroüreterektomi, nefrektomi ve prostatektomi operasyonu geçiren hastaların ortalama

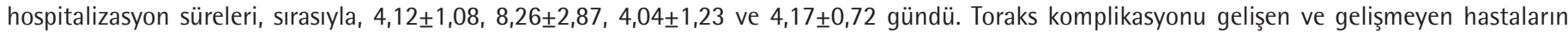
ortalama hospitalizasyon süreleri arasında anlamlı bir farklılık yoktu $(p=0,729)$.

Sonuç: Ürolojik girişimler sonrası torasik komplikasyonlar gelişebilir. Özellikle sağ taraflı perkutan nefrolitotomi ve nefrektomi sonrası göğüs ağrısı tarifleyen hastaların akciğer grafisi ile değerlendirilmesi erken tanı için önemlilik arz etmektedir.

Anahtar Kelimeler: Pnömotoraks, Hidropnömotoraks, Komplikasyon, Perkütan Nefrolitotomi, Nefrektomi

\section{Introduction}

Each surgical procedure has a certain risk of complications. Urological surgery, whether open or endoscopic, may be associated with visceral, vascular and thoracic complications. Along with technical and technological advances, in recent years, urologic surgery has evolved from open to endourological methods. With the increase in the number and complexity of cases, the complications caused by surgery have become inevitable. So far, there has been no overrepresentation in the literature on the thoracic complications of urological surgeries, with a focus on vascular and visceral complications $(1,2,3)$. Moreover, most of these complications are related to laparoscopic surgery. A multi-center study focused on pleural damage in laparoscopic renal surgery (4). In another large study, thoracic complications encountered during laparoscopic urology were discussed under the headings medical pulmonary complications, surgical thoracic complications, and subclinical and incidentally detected gas collections in the thorax (5).

Urological surgery itself can often be the cause of thoracic complications, and the position given to the patient may also cause complications. A case of upper lobe atelectasis due to lateral decubitus position during radical nephrectomy under general anesthesia that was successfully treated with saline lavage and bronchoscopic suction has been reported (6). Therefore, urologic surgery-related thoracic complications should be comprehensively considered in conjunction with their etiology and course and treatment methods. In this retrospective analysis, we evaluated thoracic complications occurred in patients, who were operated in our clinic, their etiology and the methods of management performed by thoracic surgery.

\section{Materials and Methods}

\section{Patients and Selection Criteria}

A total of 48 patients who were operated in the urology clinic and required perioperative and/or postoperative thoracic surgery consultation between January 2014 and December 2017 were the material of this study. Patients, who had pneumothorax, pleural effusion, hydropneumothorax or diaphragm injury due to surgical intervention or anesthesia technique and were managed by the thorax surgery clinic $(n=42)$, were included in the study. Patients who had preoperative diaphragm invasion due to local tumor spread $(n=2)$ and underwent perioperative diaphragm incision $(n=4)$ were excluded. The data of the patients were obtained from the hospital registry system and patient files in the urology and thoracic surgery clinics. The study was carried out in accordance with the principles of the Declaration of Helsinki and all patients included in the study gave consent for research use of their data, provided their identities would be kept confidential.

\section{Management Techniques of Patients}

Appropriate follow-up, oxygen inhalation therapy, thoracentesis or tube thoracostomy (T) treatments were applied by the department of thorax surgery.

\section{Data Collection and Analysis}

Demographic data of the patients, urological procedures, thoracic complications and treatment methods applied by the thoracic surgeons were analyzed. The characteristics of the patients with and without thoracic complications were compared by using the unpaired t-test. $P$ values less than 0.05 were considered statistically significant.

\section{Results}

Of the 42 patients included in the study, 27 (64.3\%) were male and $15(35.7 \%)$ were female. The mean age was $52.81 \pm 16.15$ (23-85) years. Pneumothorax was the most common thoracic complication (61.9\%) followed by pleural effusion, diaphragmatic injury, and hydropneumothorax $(17.2 \%, 17.2 \%$ and $9.5 \%$, respectively). It was observed that pneumothorax most often developed after percutaneous nephrolithotomy (PCNL) $(n=15)$. 
The other patients who developed pneumothorax were those who have undergone nephrectomy $(n=8)$, prostatectomy $(n=2)$ and laparoscopic nephroureterectomy $(n=1)$. The diagnosis of pneumothorax was most frequently made in the early postoperative period $(n=16)$. In addition, it was made on the postoperative $1^{\text {st }}$ day in 5 patients and postoperative day 4 in 1 patient.

Thoracic complications observed according to urological interventions are given in Table 1.

Only 5 patients required $\pi$. The mean duration of drainage was 4.6 \pm 2.1 (2-8) days. Other patients were followed up with oxygen inhalation. Isolated pleural effusion was seen in 6 patients. Three of these patients underwent PCNL and 3 underwent nephrectomy. Three of these patients underwent $\Pi$ and 3 had thoracentesis. The mean drainage time was $6.66 \pm 5.51$ (3-13) days in these patients. The implementation of a $\Pi$ for hemothorax developing in the left thorax after PCNL is shown in Figure 1.

All patients who developed hydropneumothorax had undergone nephrectomy. Three patients underwent $\Pi$ and the mean drainage time was $5.66 \pm 2.89$ (4-9) days. Patients with iatrogenic diaphragmatic injury were diagnosed in the perioperative period and all of them had undergone nephrectomy. In these patients, diaphragm was repaired primarily and $\Pi$ was applied in 5 patients. The mean duration of drainage was $5.2 \pm 2.28$ (2-8) days in these patients. The management of thoracic complications and the duration of thoracostomy tube drainage are summarized in Table 2.

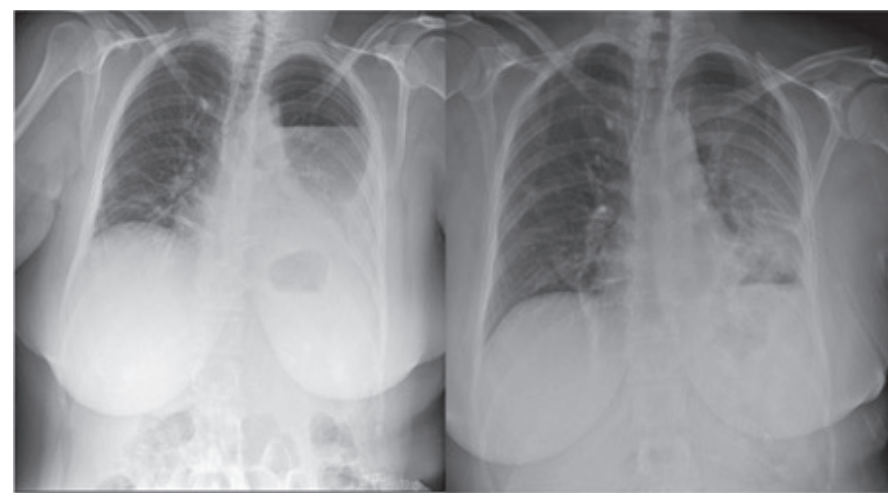

Figure 1. Left-sided thoracic tube application as a result of hemothorax after percutaneous nephrolithotomy

Table 1. Distribution of thoracic complications according to urological interventions

\begin{tabular}{|c|c|c|c|c|c|c|}
\hline \multirow[t]{2}{*}{ Variable $^{1}$} & & \multicolumn{4}{|c|}{ Thoracic complication } & \multirow[t]{2}{*}{$\mathbf{n}$} \\
\hline & & Pneumothorax & $\begin{array}{l}\text { Pleural } \\
\text { effusion }\end{array}$ & $\begin{array}{l}\text { Diaphragmatic } \\
\text { injury }\end{array}$ & Hydropneumothorax & \\
\hline \multirow[t]{3}{*}{$\begin{array}{l}\text { Urological } \\
\text { intervention }\end{array}$} & $\begin{array}{l}\text { Percutaneous } \\
\text { nephrolithotomy }\end{array}$ & 15 (83.3) & $3(16.7)$ & 0 & 0 & $18(100)$ \\
\hline & Nephroureterectomy & $1(100)$ & 0 & 0 & 0 & $1(100)$ \\
\hline & Nephrectomy & $8(38.1)$ & $3(14.3)$ & $6(28.6)$ & $4(19.0)$ & $21(100)$ \\
\hline \multirow[t]{2}{*}{ Sex } & Female & $9(60)$ & $3(20)$ & $1(6.7)$ & $2(13.3)$ & $15(100)$ \\
\hline & Male & $17(63)$ & $3(11.1)$ & $5(18.6)$ & $2(7.3)$ & $27(100)$ \\
\hline \multirow[t]{2}{*}{ Side } & Right & $20(74)$ & $1(3.7)$ & $5(18.6)$ & $1(3.7)$ & $27(100)$ \\
\hline & Left & $6(40)$ & $5(33.3)$ & $1(6.7)$ & $3(20)$ & $15(100)$ \\
\hline
\end{tabular}

'Values are given as numbers (percentage)

Table 2. Treatments applied for thoracic complications and duration of the thorax tube drainage

\begin{tabular}{|c|c|c|c|c|c|c|}
\hline \multirow[t]{2}{*}{ Variable } & & \multicolumn{4}{|c|}{ Thoracic complication } & \multirow[t]{2}{*}{$\mathbf{n}$} \\
\hline & & Pneumothorax & Pleural effusion & $\begin{array}{l}\text { Diaphragmatic } \\
\text { injury }\end{array}$ & Hydropneumothorax & \\
\hline \multirow[t]{5}{*}{ Treatment $^{1}$} & Follow-up & $21(91.4)$ & 0 & $1(4.3)$ & $1(4.3)$ & $23(100)$ \\
\hline & Thoracentesis & 0 & $3(100)$ & 0 & 0 & $3(100)$ \\
\hline & Tube thoracostomy & $5(31.3)$ & $3(18.7)$ & $5(31.3)$ & $3(18.7)$ & $16(100)$ \\
\hline & Primary repair & 0 & 0 & $5(100)$ & 0 & $5(100)$ \\
\hline & $\begin{array}{l}\text { Thorax tube } \\
\text { duration time } \\
\text { (day) }^{2}\end{array}$ & $4.6 \pm 2.19(2-8)$ & $6.66 \pm 5.51(3-13)$ & $5.2 \pm 2.28(2-8)$ & $5.66 \pm 2.89(4-9)$ & - \\
\hline
\end{tabular}

Values are given as numbers (percentage)

${ }^{2}$ Values are given as number \pm standard deviation (minimum-maximum) 
PCNL was performed in 706 patients, nephroureterectomy in 95, nephrectomy in 819 and prostatectomy in 1565 patients during the study period. The rate of thoracic complications for PCNL, nephroureterectomy, nephrectomy and prostatectomy operations was $2.54 \%, 1.05 \%, 2.56 \%$ and $0.13 \%$, respectively.

The mean length of hospital stay in patients who underwent PCNL, nephroureterectomy, nephrectomy and prostatectomy with thoracic complications was $4.12 \pm 1.08$, $8.26 \pm 2.87$, $4.04 \pm 1.23$ and $4.17 \pm 0.72$ days, respectively. In the same period, the mean length of hospital stay in patients who underwent PCNL, nephroureterectomy, nephrectomy and prostatectomy without thoracic complications was $3.28 \pm 0.68,7.11 \pm 1.79$, $3.04 \pm 0.62$ and $4.13 \pm 0.69$ days, respectively. There was no significant difference in mean length of hospital stay between the two groups $(p=0.729)$.

\section{Discussion}

Different thoracic complications may be encountered after both open and endo-urological operations. This article, in which we presented the thoracic complications and the treatment methods applied for them, revealed that the most common thoracic complication was pneumothorax and nephrectomy was the most common operation following thoracic complications. Follow-up was the most common management method for thoracic complications utilized by the thoracic surgery. $\Pi$ was the second most commonly used intervention after follow-up. The classification system, which was first described in 1992 by Clavien et al. (7) to convey a recognition and standardization of surgical complications, has been modified in 2004 (8). This system is widely accepted for the classification of surgical complications and classifies them in a spectrum ranging from grade I to V. Pulmonary complications are included in all subgroups and those constitute important components of the classification. For instance, atelectasis requiring physiotherapy

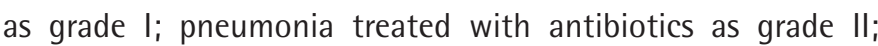
bronchopleural fistulas requiring surgical closure after thoracic surgery as grade IIlb; respiratory failure requiring intubation as grade IVa, and renal failure in addition to grade IVa is classified as grade IVb complication.

Pneumothorax may be due to several reasons after abdominal surgery. It can be seen as a complication of anesthesia as well as surgical procedure. Laparoscopic and open surgery may induce pneumothorax with different mechanisms. Congenital diaphragmatic defects may allow peritoneal carbon dioxide $\left(\mathrm{CO}_{2}\right)$ to pass into the pleural space in laparoscopic surgery $(9,10)$. $\mathrm{CO}_{2}$ may cause pneumothorax by dissecting the pulmonary hilum after entering the mediastinum or through a rupture in the mediastinal pleura and entering the pleural cavity (10). In addition, apical pneumothorax may occur due to rupture of apical blebs due to barotrauma caused by positive pressure in mechanical ventilation (9). Needle aspiration of the pleura can help distinguish whether the pneumothorax is due to endotracheal anesthesia or the $\mathrm{CO}_{2}$ accumulation into the tissue. In our series, pneumothorax most commonly occurred in patients undergoing PCNL. All these patients had upper calyceal stones and had undergone high level-needle access (10-11 or 11-12 rib interspace). During this time, maximum expiratoryinspiration maneuver was performed in coordination with anesthesia. This maneuver and high level-needle access are likely to cause this complication. Asymptomatic $\mathrm{CO}_{2}$ pneumothorax typically spontaneously resolves with conservative management. It regressed with $\mathrm{O}_{2}$ support in the majority of our patients; only 5 patients required $\Pi$. They were also treated with short-term tube drainage. Two patients who underwent prostatectomy had pneumothorax. These cases were performed by open surgery. We consider that barotrauma was the possible etiologic factor in these patients. In order to prevent abdominal gas collections, it is important to maximize abdominal muscle relaxation and prevent coughing and straining, especially during laparoscopy (11). If an intraoperative pleural or diaphragmatic damage occurs, the anaesthesiologist should be warned immediately. Ventilator parameters should be carefully controlled and allowed to complete the surgical procedure and repair any damage.

The risk of a pleural or lung injury during PCNL operation is about $10 \%$ when the puncture is above the $12^{\text {th }}$ rib. If pleural effusion occurs, a thorax tube is required. The choice of lower caliceal access and the combination with flexible nephroscope or extracorporeal shock wave lithotripsy may prevent this complication $(12,13)$. Pleural effusion occurred in our patients who underwent PCNL and nephrectomy. These patients were treated with thoracentesis or $\Pi$. The rates of thoracic complications after PCNL have been reported to be between 0\% and $11.6 \%$ in different studies $(14,15,16)$. In our study, it was found to be $2.54 \%$ in accordance with the literature.

Diaphragmatic damage is a rare but well-diagnosed complication of renal surgery. Particularly in upper pole tumors, tear of the diaphragm during dissection due to tumor invasion or injury damage due to the cautery may occur. In this complication, primary repair of the damage site is the most appropriate approach. In open surgery, primary suturing and underwater drainage can be performed, and in laparoscopic surgery, repair of the damaged area by intracorporeal suturing can be performed. A diaphragmatic injury that occurred during laparoscopic nephrectomy was treated with intracorporeal suturing and chest tube, and the $\mathrm{CO}_{2}$ pneumothorax was rapidly resorbed (9). Gonzalez et al. (17) described an alternative method for repairing diaphragmatic damage occurring during 
hand-assisted laparoscopic nephrectomy. The authors patched a polypropylene and polyglactin dual mesh with a laparoscopic stapler on the tear of diaphragm and then inserted a chest tube. The patient recovered without sequelae. In another case, gelatin matrix was used as an alternative to suturing for repairing a diaphragmatic tear. Gelatin thrombin matrix was applied to the tear area through a trocar and the defect was successfully repaired (18). This method can be successfully applied in selected small diaphragmatic defects. The rate of thoracic complications after open renal surgery has been reported to be between 3\% and $10 \%$ in different studies $(19,20)$. In our study, it was found to be between $1 \%$ and $2.5 \%$, less than in the literature. The probable cause of this low rate was our advanced experience in renal surgery and the prevention of high gas pressure by providing coordination with anesthesia during laparoscopic surgery. Recently, in a prospective study, factors that predicted pleural injury during PCNL were evaluated. Three hundred thirty-two patients were divided into two groups according to development of pleural injury and the higher risk of pleural injury was found to be associated only with low body mass index and younger age in multivariate analysis (21).

\section{Study Limitations}

Although our study is one of the rare studies presenting thoracic complications of urological surgeries from a single-center, it is not without limitations. Firstly, limited number of cases and its retrospective nature are the main limitations. Second, direct radiography with lower sensitivity was used in the diagnosis of pleural complications instead of computed tomography.

\section{Conclusion}

In conclusion, it should be kept in mind that thoracic complications may occur during urological surgeries. It is essential to diagnose complications (perioperative if possible) immediately and to work in coordination with anesthesiologists and to consult with thoracic surgeons.

\section{Ethics}

Ethics Committee Approval: Retrospective study.

Informed Consent: Informed written informed consent was obtained from all patients included in our study.

Peer-review: Externally peer-reviewed.

\section{Authorship Contributions}

Concept: F.K., T.I.A., Design: F.K., T.I.A., Data Collection and/ or Processing: F.K., T.I.A., S.K., A.Ş., B.T., Ö.K., U.Ç., O.N., C.Ö., i.C. Analysis and/or Interpretation: F.K., T.I.A., Ö.K. Literature Research: F.K., T.I.A., Writing: F.K.
Conflict of Interest: No conflict of interest was declared by the authors

Financial Disclosure: The authors declare that they have no relevant financial.

\section{References}

1. Bishoff JT, Allaf ME, Kirkels W, Moore RG, Kavoussi LR, Schroder F Laparoscopic bowel injury: incidence and clinical presentation. J Urol 1999;161:887-890.

2. Siqueira TM Jr, Kuo RL, Gardner TA, Paterson RF, Stevens LH, Lingeman JE, Koch MO, Shalhav AL. Major complications in 213 laparoscopic nephrectomy cases: the Indianapolis experience. J Urol 2002;168:1361-1365.

3. Meraney $A M$, Samee AA, Gill IS. Vascular and bowel complications during retroperitoneal laparoscopic surgery. J Urol 2002;168:1941-1944.

4. Del Pizzo JJ, Jacobs SC, Bishoff JT, Kavoussi LR, Jarrett TW. Pleural injury during laparoscopic renal surgery: early recognition and management. J Urol 2003;169:41-44.

5. Abreu SC, Sharp DS, Ramani AP, Steinberg AP, Ng CS, Desai MM, Kaouk JH, Gill IS. Thoracic complications during urological laparoscopy. J Urol 2004:171:1451-1455.

6. Kabaria V, Sofair $E$, Kubal K. Right upper lobe atelectasis after upper urinary surgery in the lateral decubitus position--case report. Middle East J Anaesthesiol 1994;12:417-428.

7. Clavien PA, Sanabria JR, Strasberg SM. Proposed classification of complications of surgery with examples of utility in cholecystectomy. Surgery 1992;111:518-526.

8. Dindo D, Demartines N, Clavien PA. Classification of surgical complications: a new proposal with evaluation in a cohort of 6336 patients and results of a survey. Ann Surg 2004;240:205-213.

9. Venkatesh R, Kibel AS, Lee D, Rehman J, Landman J. Rapid resolution of carbon dioxide pneumothorax (capno-thorax) resulting from diaphragmatic injury during laparoscopic nephrectomy. J Urol 2002;167:1387-1388.

10. $\mathrm{Ng} \mathrm{CS}$, Gill IS, Sung GT, Whalley DG, Graham R, Schweizer D. Retroperitoneoscopic surgery is not associated with increased carbon dioxide absorption. J Urol 1999;162:1268-1272.

11. Doctor $\mathrm{NH}$, Hussain Z. Bilateral pneumothorax associated with laparoscopy A case report of a rare hazard and review of literature. Anaesthesia $1973 ; 28: 75-81$.

12. Netto NR Jr, Ikonomidis J, Ikari O, Claro JA. Comparative study of percutaneous access for staghorn calculi. Urology 2005;65:659-662.

13. Gupta R, Kumar A, Kapoor R, Srivastava A, Mandhani A. Prospective evaluation of safety and efficacy of the supracostal approach for percutaneous nephrolithotomy. BJU Int 2002;90:809-813.

14. Singh I, Singh A, Mittal G. Tubeless percutaneous nephrolithotomy: is it really less morbid? J Endourol 2008;22:427-434.

15. Gupta N, Mishra S, Nayyar R, Seth A, Anand A. Comparative analysis of percutaneous nephrolithotomy in patients with and without a history of open stone surgery: single center experience. J Endourol 2009;23:913-916.

16. Semins MJ, Bartik L, Chew BH, Hyams ES, Humphreys M, Miller NL, Shah O, Paterson RF, Matlaga BR. Multicenter analysis of postoperative CT findings after percutaneous nephrolithotomy: defining complication rates. Urology $2011 ; 78: 291-294$.

17. Gonzalez CM, Batler RA, Feldman M, Rubenstein JN, Nadler RB, Schoor RA. Repair of a diaphragmatic injury during hand assisted laparoscopic nephrectomy using an onlay patch of polypropylene and polyglactin mesh. J Urol 2002;167:2512-2513. 
18. Bhayani SB, Grubb RL 3rd, Andriole GL. Use of gelatin matrix to rapidly repair diaphragmatic injury during laparoscopy. Urology 2002;60:514.

19. Dunn MD, Portis AJ, Shalhav AL, Elbahnasy AM, Heidorn C, McDougall EM, Clayman RV. Laparoscopic versus open radical nephrectomy: a 9-year experience. J Urol 2000;164:1153-1159.
20. Weinstein SH, Navarre RJ Jr, Loening SA, Corry RJ. Experience with live donor nephrectomy. J Urol 1980;124:321-323.

21. Sharma K, Sankhwar SN, Singh V, Singh BP, Dalela D, Sinha RJ, Kumar M, Singh $M$, Goel A. Evaluation of factors predicting clinical pleural injury during percutaneous nephrolithotomy: a prospective study. Urolithiasis 2016;44:263-270. 